Оригинални научни рад

УДК 821.133.1.09-2“15/16“

Примљен: 31. март 2021.

Прихваћен: 10. априла 2021.

Вања В. Цветковић ${ }^{1}$

Универзитет у Нишу

Филозофски факултет

Департман за француски језик и књижевност

\title{
ТЕОРИЈА ДРАМЕ ФРАНЦУСКОГ РОМАНТИЗМА: ИЗМЕЂУ РАСИНА И ШЕКСПИРА ${ }^{23}$
}

Овај рад настоји да понуди сажети преглед основних поставки теорије драме француског романтизма која је настала као реакција на класичну трагедију француског 17. века, а истовремено и као продужетак Дидроове теорије о грађанској драми из 18. века. Нова драматургија изложена је у два кључна списа који ће бити основни предмет анализе: Стендалов Расин $u$ Шекспир и Игоов Предговор Кромвелу. Међутим, критички осврт на драмску праксу епохе француског романтизма намеће преиспитивање, а тиме и ново вредновање романтичарских теорија о драми. У том погледу, истраживање ће се позвати на студију Џорџа Стајнера Смpm трагедије како би размотрило стварни домашај теоријског разматрања романтичара. Најпре ћемо изложити стање позоришта, друштва и политике у Француској у одабраном периоду, затим представити романтизам као књижевну револуцију, да бисмо се потом надовезали на теорију драме и њену друштвено-политичку обојеност, те коначно утврдили да ли је драма француског романтизма поетички ближа $\mathrm{Pa}$ сину, представнику класицизма у позоришту, или Шекспиру, новооткривеној инспирацији романтичара.

Кључне речи: теорија драме, драматургија, романтизам, Расин и Шекспир, Предговор Кромвелу, трагедија

Да би се уопште могло говорити о теорији драме француског романтизма 19. века, која суштински представља продужетак Дидроове

1 vanja.cvetkovic@filfak.ni.ac.rs

2 Рад је настао у оквиру научноистраживачког пројекта Романистика и словенски језииц, кюижевности и културе у контакту и дисконтакту (бр. 1001-13-01) који финансирају Филозофски факултет Универзитета у Нишу, Универзитетска агенција за франкофонију (AUF - Agence universitaire de la francophonie) и Амбасада Републике Француске у Србији (Ambassade de France en Serbie).

3 Део овог рада под насловом „Теорија драме француског романтизма“ био је представљен у виду усменог саопштења на Међународном научном скупу Језик, књижевност, теорија на Филозофском факултету Универзитета у Нишу који је одржан 27-28. априла 2018. године. 
(Denis Diderot) теорије грађанске драме (drame bourgeois) из претходног столећа, неопходно је најпре поменути класичну трагедију 17. века од које је све почело. Иако романтичари, по угледу на Дидроа, драму теоријски конципирају као супротност класичној трагедији, а нову поетику прокламују као ослобођење од строгих правила француског класицизма и пропагирају демократизацију уметности, са данашње дистанце можемо увидети да се они у ствари нису много удаљили од позоришног модела који су наизглед строго нападали. Мада је неминовно да би романтичарска драма требало да представља антипод класичарској трагедији и коначни раскид са неоантичким стваралачким маниром, ту тежњу за стварањем драмског облика који би био саобразан актуалној друштвеној стварности и ближи свакодневном животу не треба разумети као жељу за потпуним уништењем трагедије. Напротив, Џорџ Стајнер (George Steiner) у студији Cмрт mрагедије (The Death of tragedy) бележи да у исходишту романтичарског покрета лежи експлицитан покушај ревитализације њених главних облика (STAJNER 1979: 80).

Управо ће тај покушај бити у средишту овог разматрања које за циљ има да објасни на који је начин конституисана теорија драме француског романтизма, да испита да ли је она заиста толико искључива према класицистичкој поетици како се најчешће представља, као и да критички сагледа њене домете. Стога, ваља нам поставити питање: трагедија или драма, односно, по угледу на Стендала (Stendhal) чији ће се драматуршки спис наћи у средишту нашег истраживања - Расин или Шекспир?

\section{1. Позориште, друштво, политика}

Француска класична трагедија, поетички нормирана у Боалоовом спису Песничка уметност (Nicolas Boileau, L’Art poétique), доживела је свој врхунац у 17. веку, у делима Расина (Jean Racine) и Корнеја (Pierre Corneille), за време владавине Луја XIV која се често узима као историјски пандан златној епохи класицизма. Сходно томе, слабљење утицаја класичне трагедије календарски одговара кризи Старог режима (Ancien régime) која је нарочито изражена у 18. веку. И док ће француска буржоаска револуција 1789. године означити његов крај, трагедија ће ипак опстати и кроз 18. век. Мада је Волтерова (Voltaire) литерарна амбиција "osigurati kontinuitet francuske tragedije, nastaviti djelo tih velikih klasika" (DŽAKULA 1978: 89) наишла на добар пријем код публике, Бранко Џакула у другој књизи едиције Француска књижевност закључује да његово драмско стваралаштво припада само историји књижевности, јер је „bez dublje unutarnje motivacije i bez pravog pjesničkog žara" (DŽAKULA 1978: 91). За разлику од Волтера који је настојао да уношењем одређених иновација на плану садржаја ипак одржи критичку дистанцу према претход- 
ницима (DŽAKULA 1978: 89), други поборници класицизма из 18. века настојали су да пишу трагедије по угледу на узоре - Расина и Корнеја, и даље робујући класицистичким правилима како у погледу форме, тако и у погледу садржаја. Међутим, трагедија у промењеним друштвено-политичким околностима и измењеном погледу на свет млађе генерације није могла успети.

Сматрајући да је драма као врхунски књижевни облик огледало људског друштва, а да је „vitalnost drame neodvojiva od zdravlja opće politike“ (STAJNER 1979: 81), француски романтичари у 19. веку настоје да трагедији подаре нови живот који ће одговарати новим идеолошким струјањима и духу епохе. Док је за време краљевања Луја XIV позориште представљало „ne samo jednu od najplemenitijih zabava već i neku vrstu društvene obaveze uglađenog čoveka“ (DŽAKULA 1978: 22), у немирним временима револуције у 18. и, касније, у првој половини 19. века оно добија све запаженију политичку функцију - постаје место друштвеног окупљања и политичког разговора, центар грађанског живота који је уобличавао друштвену свест и изграђивао моралну одговорност заједнице. На тај начин је у другој половини 18. века рођена драма, тј. Дидроова грађанска драма, ${ }^{4}$ као позоришни облик близак грађанском свакодневљу који је преносио актуалне политичке и етичке идеје писаца-философа, те који је требало да постане књижевни пандан буржоаској револуцији и означи крајњи пад старог, тј. класицистичког режима.

Дидро и његови теоријски следбеници веровали су да позоришна уметност треба да постане „грађанска школа етике и политике“, како напомиње Нермин Вучељ у раду Дидактички театар епохе франиуског просветительства и појашњава:

„С обзиром на то да је у XVIII веку трагедија епохе француског класицизма сматрана одразом превазиђених друштвених односа, заснованих на начелима наметнутим од стране аристократије, која је умеђувремену изгубила пређашње привилегије, грађанско друштво епохе просветитељства настојало је да кроз позоришни израз наметне нову духовност, другачије политичке погледе и своје друштвене идеале" (VUČELJ 2012: 165).

Тако је позориште од аристократске разоноде постало одраз грађанског живота у коме осећања трагичног и комичног нису строго одвојена као што је то био случај на класицистичкој сцени, а теме које су занимале публику превазилазиле су митолошке и псеудоисторијске

4 Дидроова драмска начела изложена су у Разговорима о „Ванбрачном сину“ (Entretiens sur «Le Fils naturel », 1757) и у расправи О драмској поезији (De la poésie dramatique, 1758), да би онда његове идеје преузео Бомарше у бројним расправама, а онда и Мерсје у Новом есеју о драмској уметности (Nouvel Essai sur l'art dramatique, 1773). 
оквире. Из тог разлога је створена драма као књижевна врста „у којој се елементи трагедије и комедије мешају најчешће у циљу озбиљног приказивања тема из свакодневног живота“" (KOLJEVIĆ 1992: 133), а у центру њених збивања била је грађанска класа као покретачка снага политичког живота која ће крајем 18. столећа изнедрити револуцију. Драма је настала као одраз буђења грађанске свести, нове духовности, политичких погледа и друкчијих друштвних односа чиме је требало да најзад смени класичну трагедију.

Међутим, Дидроова теорија није успела у пракси: драме 18. века прошле су неславно због подилажења сентиментално-сладуњавом укусу публике и инсистирању на морализаторском карактеру комада, како оцењује Нермин Вучељ (VUČELJ 2012: 174). Истовремено је и друштвено-идеолошки пандан драми, француска буржоаска револуција, изневерила очекивања и, уместо у демократији и владавини права, завршила у Робеспјеровом терору и, касније, Наполеоновој диктатури и царству. Но, тај неуспех не умањује важност 18. века који је наредној генерацији у идеолошком смислу оставио борбени карактер, љубав према слободи и демократским вредностима, а у уметничком драму у зачетку и оно што је у њој највредније, по мишљењу француског теоретичара Гефа и најлепше - њену теоријску намеру, изнету као поетичко начело, „а то је да служи човеку“ (VUČELJ 2012: 174). Романтичари ће, дакле, из епохе просветитељства наследити драму као револуционарни књижевно-сценски облик који ваља ојачати и прилагодити идеолошким стремљењима сопствене генерације која ће, такође, имати своју револуцију.

\section{2. Романтизам као књижевна револуција}

Осамнаести век је кључан за формирање романтизма као правца јер је револуција, као покрет политичког и духовног ослобођења уопште који је разбијао све стеге, „utirala put romantičarskom pokretu čiji je jedan od glavnih ciljeva bilo oslobađanje umetnosti”, напомиње Михаило Павловић у другом тому едиције Франиуске књижевности (PAVLOVIĆ 1978: 240). То ослобађање подразумева одбацивање класичне поетике француског 17. века засноване на строгим формалним правилима и имитацији античких песничких узора, бележи Карл Пети (Karl Petit) у Златној къизи романтизма (Le livre dor du Romantisme), али и превагу осећања над разумом, увођење индивидуализма и лиризма у књижевност и потпуну слободу израза (PETI 1968: 277). Свакако, не треба заборавити ни друштвено-политички значај тог ослобађања. Друштвено свесни и грађански савесни, романтичари кроз либерализацију уметности настоје да ослободе друштво не само од политичких притисака, већ и од уврежених поетичких догми које Француска академија, врховна институција културе, образовања и уметности, настоји да одбрани. Зато Пети каже да 
романтизам није само једна „лепа епоха“, већ је то период побуне против опресивних институција када друштво захтева успостављање реда и правде (РЕTI 1968: 277).

За романтизам је, онда, од пресудног значаја дејство револуције „u smislu razvijanja individualizma, rušenja hijerarhije u društvu i njegovu demokratizaciju, što je bio podstrek za iste pojave u umetnosti“, вели Михаило Павловић и закључује да ће управо зато романтичарска књижевност „іс́і na proširenje publike u težnji da osećanja i ideje zajedničke svim ljudima uputi svakom čoveku”; тако ће песник „biti prorok koji se obraća celom narodu, a ne jednoj eliti“ (PAVLOVIĆ 1978: 240). У оваквој борби за отварање уметности ка широј публици и њену демократизацију огледа се општа тежња француског друштва на преласку 18. у 19. век да буде више укључено у актуалну политичку стварност и државно уређење. Овај историјски период у Француској био је праћен великим политичким превирањима која ће се наставити и кроз прву половину 19. века, а што ће неминовно утицати и на романтизам. Он своју зрелу фазу доживљава у периоду од пада Наполеона 1815. године и доласка династије Бурбон на престо (тј. Рестаурације), преко Јулске револуције до конституисања Јулске монархије: „, to je vreme postupne ideološke preorijentacije, napuštanje monarhizma i verskog zanosa i javljanje progresivnih težnji i socijalnih preokupacija" (PAVLOVIĆ 1978: 240). Дакле, француско друштво се у првој половини 19. века борило за поновно успостављање либералних и демократских вредности рушењем, или макар ограничавањем апсолутистичке владавине краља, а тај је слободарски дух био присутан у уметности, нарочито у позоришту које је снажило драму као одраз важних друштвених промена.

На овај начин се, управо преко позоришта као кључног медија у друштву, револуционарних идеја и слободољубивог духа аутора, епохе просветитељства и романтизма у француској драмској уметности повезују у настојању да у позориште врате обичног човека, друштвено-политичку актуалност и стваралачку слободу, те да тиме смене тематски превазиђену и формално круту трагедију епохе француског класицизма. Тако се револуције из 18. и 19. века могу посматрати као реакције на 17. век и то на два плана: на друштвено-историјском и политичком, као побуне против апсолутизма оличеног у владавини Луја XIV, а касније и у Наполеоновом царевању, а онда и на уметничко-драмском, као рушење класичне трагедије из доба Краља Сунца која је потрајала кроз читав 18. век и успостављање драме као доминантног позоришног облика ближег обичном човеку и непосредној друштвеној стварности. Настала у епохи просветитељства, драма је наставила да се развија и јача као друштвено делотворно средство и у првој половини 19. века којим су писци романтизма позивали на поновно буђење грађанске свести. 
У том светлу, романтичарски захтев за слободом израза не треба разумети само у поетичко-формалном смислу, већ и у мисаоно-идеолошком. Виктор Иго (Victor Hugo) у Предговору драми Ернани (Hernani) чији делимични превод проналазимо у књизи Зорана Глушчевића Романтизам, објашњава да је романтизам „слободоумље у књижевности“ које ће бити исто тако популарно као политички либерализам; зато је двоструки циљ романтизма „слобода у уметности, слобода у друштву“. Романтичари своју револуцију подижу против „ултраша свих врста“ класицистичких и монархистичких - јер је „књижевна слобода кћи политичке слободе“ (IGO 1967: 111,112). Драма ће у романтизму тако добити двоструки циљ: да се, рушећи канон класицистичке драме, тематски приближи просечним грађанима и њиховом свакодневљу, те се тако укључи у њихово политичко делање, као и да се формално ослободи нормативне псеудоаристотеловске поетике чиме би се симболично ослободила присилних институционалних оквира и других притисака власти.

\section{3. Теорија драме француског романтизма}

Теоријска мисао о драми дуго је сазревала код француских романтичара ${ }^{5}$ да би кулминирала у трећој деценији 19. века када је објављен велики број памфлета и комада који је требало да ојачају романтичарску позоришну револуцију познатију под називом романтичарска битка (la bataille romantique). ${ }^{6}$ Један инцидент у позоришту додатно

5 Мада теорија драме француског романтизма врхунац доживљава у раније поменутим текстовима Виктора Игоа и Стендала, ваља нагласити да су идеје за стварањем романтичарске драме биле присутне и раније. Како напомињу аутори француске едиције посвећене књижевности 19. века Андре Лагард и Лоран Мишар (André Lagarde, Laurent Michard), оне су се почетком прве четвртине 19. века преносиле преко разговора, разних предговора и новинских чланака (LAGARD, MIŠAR 1969: 231). Аргументе против класичне трагедије романтичари су тражили и у преводима и адаптацијама дела и предговора немачких драматурга, а најважнији списи који су им у томе помогли били су: Шлегелов Час драмске къижевности (преведен на француски 1814. године) који слави Шекспира и излаже основне принципе романтичарске драме, Манцонијево Писмо о драмским јединствима (написано 1820, објављено 1823. године), као и Ремисоови чланци у часопису Глоб (Le Globe), прецизни су Лагард и Мишар (LAGARD, MIŠAR 1969: 231). Уз то, треба рећи да у списима раних француских романтичара попут Шатобријана (Chateaubriand), Бенжамена Констана (Benjamin Constant), Госпође де Стал (Madame de Staël) и др. проналазимо промишљања и очигледан немачки утицај који ће и те како допринети развоју касније теорије.

6 То је назив за поетичко-идејни сукоб који се води између романтичара, као представника новог књижевног покрета, и заосталих поборника класицизма као старог и превазиђеног правца у књижевности који ће почети негде око 1823. године и завршити се 1830. у виду тријумфа Игоове иначе забрањене драме Ернани у француском националном позоришту Comédie Française,како прецизира Павловић (PAVLOVIĆ 1978: 243). Ова победа романтизма над класицизмом у позоришту, након дуге и тешке борбе са 
jу је убрзао. Како сазнајемо у Уводу Бернара Лејоа (Bernard Leuilliot) у француском издању списа Расин и Шекспир, током 1822. године енглеске глумачке трупе са Шекспировим комадима на репертоару у неколико наврата гостују у Француској, али доживљавају велики неуспех: Парижани, навикнути на неоантичке позоришне норме присутне у тада и даље актуалном класичном позоришном маниру, с гнушањем гледају Ромеа $u$ Јулију, Отела, Ричарда III, Магбета и Хамлета. Енглески комади, тако супротни углађеном укусу француске публике, бивају извиждани. Упознат са овим скандалом, Стендал 1823. године пише први део расправе Расин и Шекспир у коме се обраћа младој француској публици која је, задојена класицизмом, неправедно извиждала Шекспира (LEJO 2005 : 7). Jер, како објашњава Стендал:

„Код тог великог човека треба подражавати начин како се проучава свет у коме живимо и вештину да пружимо својим савременицима управо ону вртсту трагедије која им је потребна, али коју не смеју да захтевају, овако заплашени славом великог Расина“ (STENDAL1953: 48). ${ }^{7}$

На тај начин, популаризовањем Шекспировог стваралачког манира, Стендал се залаже за нову драмску поетику сасвим супротну класичној позоришној школи која узор има у Расиновим трагедијама. Тиме се повод за избијање романтичарске битке и супштина сукоба између класичара и романтичара у позоришту, тј. старих и модерних, у ствари своди на избор између Расина и Шекспира:

„Сва препирка око Расина и Шекспира своди се на то да се установи могу ли се, поштујући оба јединства места и времена, написати комади који живо занимају гледаоце 19. века, комади на којима они плачу и дрхте, или, другим речима који им пружају драмска уживања, уместо епских уживања [...]“ (STENDAL1953: 15). ${ }^{8}$

Међутим, није било лако изборити се са класицизмом који је на француској позоришној сцени био устоличен скоро два века. Баш као

цензуром и окорелим укусом публике, остала је позната под називом Битка за „Ернанија" (Bataille d'Hernani).

7 «Ce qu'il faut imiter de ce grand homme, c'est la manière d'étudier le monde au milieu duquel nous vivons, et l'art de donner à nos contemporains précisément le genre de tragédie dont ils ont besoin, mais qu'ils n'ont pas l'audace de réclamer, terrifiés qu'ils sont par la réputation du grand Racine» (STENDAL $2005:$ 42).

8 « Toute la dispute entre Racine et Shakespeare se réduit à savoir si, en observant les deux unités de lieu et de temps, on peut faire des pièces qui intéressent vivement des spectateurs du $19 \mathrm{e}$ siècle, des pièces qui les fassent pleurer et frémir, ou, en d'autre termes, qui leur donnent les plaisirs dramatiques, au lieu des plaisirs épiques [...] » (STENDAL 2005 : 22). 
што је публика бурно негодовала пред Шекспировим комадима, тако је и Француска академија оштро осудила Стендалов спис и читав романтичарски покрет. Зато је Стендал 1825. године објавио други део списа Расин и Шекспир као одговор на говор академика Ожеа (Auger) који је, као представник Француске академије, годину дана раније (тачније, у обраћању 24. априла 1824. године) сурово критиковао „романтичарску секту“ и њене тековине (LEJO 2005: 12).

Но, Стендал није био усамљен у борби против Академије, нити је његово одушевљење Шекспиром било произвољно и субјективно. Стајнер напомиње да је оно било присутно међу ауторима и пре романтичарског периода, мада је романтичарски однос према Шекспиру дубљи: око шекспировске драме романтичарска осетљивост је окупила своје главне снаге, за романтичарске песнике откривање Шекспира било је велики будитељ свести, а његова су дела била узор пред свеколиком каснијом драмом (STAJNER1979: 103). Међу обожаваоцима Шекспировог стваралаштва и бранитељима романтизма нашао се и Виктор Иго. Година 1827. обележена је Шекспировом победом над Расином, и то не само због чињенице да се енглеске трупе славно враћају у француско позориште (LEJO 2005: 14), већ и зато што Виктор Иго, следећи Шескпиров стваралачки манир, објављује драму Кромвел и још чувенији Предговор Кромвелу у коме изражава дивљење према славном енглеском аутору. Наиме, према Игоу, дух романтизма најбоље се огледа у повезивању гротескног и узвишеног како би се сликањем тих опречности пренела дуалност самог живота, а то можемо научити управо из Шекспирових комада. Шекспир је поетски врхунац модерног времена ; Шекспир - то је драма, и то драма „која истим дахом слива гротескно и узвишено, страшно и лакрдијашко, трагедију и комедију“ (IGO 1967: 122). ${ }^{9}$

Поред тога што су Шекспира узели за узор у драмском стваралаштву, Стендал и Иго уједињени су и у мишљењу о другим поетичким питањима која се заснивају на негацији поетике француског класицизма, те се њихове две теорије изложене у списима Расин и Шекспир и Предговор Кромвелу стапају у једну заједничку теорију драме француског романтизма чија се главна полазишта могу свести на следеће: ${ }^{10}$

- нема песничких узора на које се треба угледати, тј. инсистира се на посебној креацији песничког генија, а не на имитацији античких модела што је био случај у класицизму;

9 «Shakespeare, c'est le drame; et le drame, qui fond sous un même souffle le grotesque et le sublime, le terrible et le bouffon, la tragédie et la comédie [...] » (IGO 2004 : 34).

10 У овом делу рада интерпретирамо и обједињујемо ставове двојице аутора о новој позоришној врсти изнете у различитим деловима списа Расин и Шекспир и Предговор Кромвелу, притом користећи оригинална и преводна издања дела наведена у попису Цитиране литературе на крају рада. 
- трагедија и комедија више нису стриктно одвојене, већ се мешају жанрови, трагично и комично, узвишено и гротескно, чиме се инсистира на двојности човекове природе и свих ствари у свету;

- нема више класичарског правила прикладности, романтичари захтевају приказивање ужасног и више акције на сцени;

- теме и мотиви преузимају се из савремене историје или средњовековног наслеђа: слика се актуална стварност или блиска прошлост чиме се у потпуности превазилазе теме из грчке и римске митологије и псеудоисторије популарне у класицизму; инсистира се на националном колориту;

- ликови су ближи обичним људима, њихов говор је мање свечан, а нагласак је на аутентичном декору и костимима;

- укидају се античка јединства времена и места захваљујући концепту позоришне илузије којој се гледалац предаје, а која подразумева његово интелектуално и емоционално учешће, тзв. уживљаване; задржава се само јединство радње без којег драма, као смислена и логичка целина, не би била могућа;

- наглашавају се осећања: патетично, страшно, драматично, комично;

- инсистира се на приказивању развоја страсти и изазивању емоционалних реакција код публике (према Стендалу, представа код гледалаца треба да изазове одређено узбуђење, афективни одговор, тзв. драмско уживаюе које је супротно од епског уживағ 6 карактеристичног за класично позориште и своди се на декламовање лепих стихова на сцени).

Премда очигледно сродне, теорије Стендала и Игоа ипак садрже две разлике. Док Иго даје предност драми у стиху, сматрајући да се стихом књижевност брани од вулгарног и обичног (IGO 1967: 132-134 ; IGO2004 : 67-69), Стендал инсистира на драми у прози јер се тако добијају природније реплике које више личе на обичан говор, избегава се крутост и претенциозност стила који треба да се свиђа „деци Револуције, људима који траже пре мисао него лепоту речи“ (STENDAL 1953: 77). ${ }^{11}$ Можда се у овој Стендаловој опасци најбоље може уочити духовна промена која се одиграла у француском друштву крајем 18. века, чији су одјеци и те како били присутни у потоњем столећу, а која је захтевала нову драмску форму блиску грађанској класи.

Уз то, присутна су и терминолошка колебања: за означавање нове драмске врсте Иго користи термин драма (drame), док је Стендал означава као нову француску трагедију (nouvelle tragédie française), односно на11 "J'ai tâché que le mien [le style] convînt aux enfants de la Révolution, aux gens qui cherchent la pensée plus que la beauté des mots » (STENDAL 2005 : 59). 
ционалну трагедију у прози или романтичну трагедију (tragédie nationale en prose ou du romantisme, tragédie romantique). Но, треба подвући да две поменуте формалне разлике ни на који начин не утичу на идејну блискост теорија. Стендал само терминолошки остаје веран трагедији, док су сви његови постулати усмерени ка креирању и дефинисању драме као споја трагичног и комичног. Он се, дакле, не удаљава од основне романтичарске тежње да новом драмском врстом смени класичну трагедију, док чињеница да ипак задржава термин трагедија указује на једну врло важну специфичност у односу романтичара према трагедији - она потврђује да њихова намера није била да сасвим униште трагедију, већ, напротив, да je, као врховну књижевну врсту, ревитализују прилагођавајући је актуалним друштвеним интересовањима и укусу својих савременика.

\section{4. Драма или нова трагедија}

Сматрајући да је, како примећује Стајнер, одсуство добре трагедије пораз друштва који оно не може поднети без последица (STAJNER 1979: 81), романтичари настоје да оживе трагедију, али да је истовремено измене и прилагоде тако да кроз њу прикажу друштвено стање и националну енергију свог доба. Они, дакле, раскидају са класичарском традицијом у погледу строгих правила прикладности и вероватности, одржавања реда и склада, поштовања јединстава времена и места, угледања на античке узоре и нормативизације поетике, премда задржавају основне карактеристике трагедије као најстаријег драмског облика. Идеја романтичара била је да тематски осавремене и формално ослободе трагедију чврстих класичарских правила, те да је, додавањем комичних елемената, претворе у позоришни облик који би живо занимао гледаоце и одговарао друштвено-политичком тренутку због чега се као кључно поставља питање актуалности. Романтичари сматрају да дешавања у драми морају побуђивати живо интересовање публике, насупрот превазиђеним темама и односима који су представљени у класицистичкој трагедији. Зато је класицизам застарео и мора бити смењен новим поетичким назорима:

„Романтицизам ${ }^{12}$ је уметност пружити народима књижевна дела која у садашњем стању њихових навика и убеђења могу да им даду највеће могућно уживање. Класицизам им, напротив, пружа књижевност која је давала највеће уживање њиховим прадедовима“ (STENDAL 1953: 42). ${ }^{13}$

12 Стендал је велики заљубљеник у Италију и њено уметничко наслеђе, те употребљава италијански термин романтицизам, уместо романтизам.

13 «Le romanticisme est l'art de présenter aux peuples les œuvres littéraires qui, dans létat actuel de leurs habitudes et de leurs croyances, sont susceptibles de leur donner le plus de plaisir possible. Le classicisme, au contraire, leur présente la littérature qui donnait le plus grand 
Стога, према Стендалу, бити романтичар у ствари значи бити актуалан, савремен, занимљив, а бити класичан значи бити превазиђен, застарео, досадан. У том светлу се одреднице романтичар и класичар у Стендаловој теорији не односе на писце који припадају двема историјско-уметничким епохама, већ оне имају квалитативни карактер. Отуд и не чуди што за пример доброг представника романтизма узима енглеског ренесансног писца, ${ }^{14}$ Молијера, или чак, парадоксално, и самог Расина: ${ }^{15}$

„аа без устезања тврдим да је Расин био романтичар; он је пружио маркизима на двору Луја XIV слику страсти ублажену изванредним достојанством које је тада било у моди и због кога какав војвода из 1670 није никад пропуштао, чак ни у најнежнијим изливима очинске љубави, да назове свог сина господином“ (STENDAL 1953: 43). ${ }^{16}$

Очигледно је да Стендал према правим класичарима попут Расина који су били романтични тј., актуални у својој епохи, гаји велико поштовање и дивљење, те стога треба нагласити да, ма како критички били настројени према нормативној поетици класицизма из 17. века, романтичари у ствари нападају продужетак класицистичког обрасца писања трагедија кроз 18. и 19. век, односно псеудокласицизам, тј. лажни класицизам и његове трагедије „подражаване према Расину“ како их на једном месту назива Стендал (STENDAL 1953: 95). ${ }^{17}$ Класицизам је у 17. веку био романтизам, тј. представљао је уметнички правац саобразан друштвеној актуалности, али га је, сходно новом социо-политичком контексту, у 19. веку неопходно променити. Како на примеру грчких трагичара сликовито објашњава Стендал, Софокле и Еурипид били су „у највећем степену романтични“ јер су својим савременицима „дали трагедије које су, према моралним навикама тог народа, његовој вери, његовим предубеђењима о

plaisir à leurs arrière-grands-pères » (STENDAL 2005 : 38).

14 „Шекспир је био романтичар јер је приказао Енглезима из године 1590, прво, крваве преврате које су грађански ратови донели, а да би их одморио од тих жалосних призора, безбројне танане слике душевних узбуђења и најнежније преливе страсти“ (STENDAL 1953: 43). / «Shakespeare fut romantique parce qu’il présenta aux Anglais de l’an 1590, d’abord les catastrophes sanglantes amenées par les guerres civiles, et pour reposer de ces tristes spectacles, une foule de peintures fines des mouvements du cœur, et des nuances de passions les plus délicates » (STENDAL 2005 : 38-39).

15 Стендал на једном месту тврди да су „сви велики писци били романтичари свог доба“ (STENDAL 1953: 92). / "Tous les grands écrivains ont été romantiques de leur temps » (STENDHAL $2005: 68$ ).

16 « Je n’hésite pas à avancer que Racine a été romantique ; il a donné aux marquis de la cour de Louis XIV une peinture des passions, tempérée par l'extrême dignité qui alors était de mode, et qui faisait qu'un duc de 1670, même dans les épanchements les plus tendres de l'amour paternel, ne manquati jamais d'appeler son fils Monsieur» (STENDAL 2005 : 38).

17 «...] plusieurs tragédies imitées de Racine» (STENDAL 2005 : 69). 
том шта чини човеково достојанство, морале прибавити му највеће уживање“ (STENDAL 1953: 43). Подражавати Софокла и Еурипида толико векова касније, „а сматрати да та подражавања неће натерати Французе XIX века на зевање, то је класицизам“ (STENDAL 1953: 43). ${ }^{18}$

У складу са тиме, романтичарски покушај конституисања драме не треба разумети као радикални раскид са позоришном традицијом, већ као неку врсту романтизације класичне трагедије, покушај њеног обнављања, осавремењивања, модернизације. Романтизам, као стваралачки манир подразумева да актуално, истинито и допадљиво треба пренети на трагедију као изворни драмски облик и тиме је приближити укусу и интересовању модерне публике. Како Стендал објашњава: „Романтизам примењен на трагичну врсту, то је трагедија у прози која траје више месеца и догађа се на различним местима“ (STENDAL 1953: 98). ${ }^{19}$ Овај цитат можда најочигледније показује како романтичари, уз одређене трансформације, ипак настављају драмско наслеђе класицизма.

Онда се ваља запитати може ли се прихватити теза коју Маријана Бири (Mariane Bury) наговештава већ у наслову свог рада - Расин и Шекспир у романтичарској биии: пуно буке ни око чега (Racine et Shakespeare dans la bataille romantique : beaucoup de bruit pour rien), те одобрити Бринетијеров (Brunetière) став изнет у Приручнику историје франиуске книжевности (Manuel de l'Histoire de la littérature française):

„Романтична драма је класична трагедија у којој имамо право да прекршимо три драмска јединства, чији ликови могу бити само обични појединци, а где се гротескно непрекидно меша са узвишеним“ (BIRI 2003: 665). ${ }^{20}$

На први поглед, чини се да би одговор на ово питање могао бити потврдан. Међутим, убрзо би постало јасно да би такво закључивање потпуно умањило значај романтичарске битке тако грубо отргнуте из друштвено-историјског контекста и анулирало револуционарни карактер романтизма, док би романтичарску драматургију од класичарске одвајало само неколико формалних разлика. Иако смо показали да теорија драме француског романтизма у одређеном смислу представља 18 «Sophocle et Euripide furent éminemment romantiques ; ils donnèrent aux Grecs rassemblés au théâtre d'Athènes les tragédies qui, d’après les habitudes morales de ce peuple, sa religion, ses préjugés sur ce qui fait la dignité de l'homme, devaint lui procurer le plus grand plaisir possible. Imiter aujourd'hui Sophocle et Euripide, et prétendre que ces imitations ne feront pas bâiller le Français du XIXe siècle, c'est du classicisme» (STENDAL 2005 : 38).

19 «Le romantisme appliqué au genre tragique, c'est une tragédie en prose qui dure plusieurs mois et se passe en divers lieux » (STENDAL 2005 : 71).

20 «Le drame romantique est une tragédie classique; où l’on a le droit de violer les trois unités ; dont les personnages peuvent nêtre que de simples particuliers ; et où le grotesque se mêle constamment au sublime». 
обнову класичне трагедије, не смемо заборавити да она ипак настоји да конституише посебну драмску врсту која ће бити блиска романтичарском необузданом сензибилитету и осећајности, допадљива укусу тадашње публике и блиска актуалним друштвено-идеолошким тежњама. Јер, суштина романтичарске теорије драме није у инсистирању на формалним променама и не може се свести на захтев за укидањем јединстава времена и места. То најбоље илуструје треће писмо из Стендаловог списа Расин и Шекспиру коме романтичар објашњава класичару да може постојати романтична трагедија „чији су догађаји случајно сажети у оквир једног дворца и у трајање од тридесет и шест часова“ управо због тога што непоштовање јединстава није оно што је чини романтичном:

„Ако разни догађаји те трагедије личе на оне које нам историја открива, ако је језик, уместо да буде епски и званичан, прост, жив, сјајан по својој природности, без тирада, неће је та случајност, свакако врло ретка, [....] спречити да буде романтична, хоћу рећи да пружи публици утиске који су јој потребни и, према томе, да освоји одобравање људи који мисле својом главом“" (STENDAL 1953: 95). ${ }^{21}$

И Иго у Предговору Кромвелу одлучно даје предност садржају над формом, уметничком генију над нормативизмом, те не пристаје да робује никаквим поетичким правилима:

„Разбијмо теорије, поетике и системе. Скинимо онај стари малтер који скрива лице уметности! Не постоје ни правила, ни узори; или боље рећи, не постоје друга правила осим општих закона природе који лебде изнад целе уметности, и посебних закона који, за сваку композициjy, проистичу из околности својствених сваком предмету“ (IGO 1967: 129). ${ }^{22}$

Овај цитат доказује да у сржи романтичарске побуне против класицизма није пука форма, већ избор тема, стваралачки манир, и потреба за антитезом као основним моделативним принципом нарочито

21 «Il peut cependant y avoir telle tragédie romantique dont les événements soient resserrés, par le hasard, dans l'enceinte d'un palais et dans une durée de trente-six heures. Si les divers incidents de cette tragédie ressemblent à ceux que l'histoire nous dévoile, si le langage, au lieu dêtre épique et officiel, est simple, vif, brillant de naturel, sans tirades, ce nest pas le cas, assurément fort rare, [,,,] qui l'empêchera d'être romantique, c'est-à-dire d'offrir au public les impressions dont il a besoin, et par conséquent d'enlever les suffrages des gens qui pensent par eux-mêmes » (STENDAL 2005 : 69).

22 «Mettons le marteau dans les théories, les poétiques et les systèmes. Jetons bas ce vieux plâtrage qui masque la façade de l'art! Il n'y a ni règles, ni modèles ; ou plutôt il n'y a d'autres règles que les lois générales de la nature qui planent sur l'art tout entier, et les lois spéciales qui, pour chaque composition, résultent des conditions d'existence propres à chaque sujet » (IGO 2004: 55). 
карактеристичним за Игоа. Зато се само делимично можемо сложити са Маријаном Бири да се романтичари преко Шекспира нису ослободили од поетичких конвенција неоантике и тако приближили стварности (jep су јој класичари већ били довољно близу [sic!]), те да се Шекспиров утицај једино учитава у увођењу фантастичног и стварању ониричке атмосфере која је недостајала на француској позоришној сцени тога доба (BIRI 2003: 665). Мада смо показали да је у теоријским списима Стендала и Игоа Шекспиров утицај много већи него што Бири уочава, треба признати да у практичном смислу он скоро сасвим изостаје.

\section{5. Домети романтичарске теорије}

Мада су француски романтичари као драматурзи умногоме утицали на развој и популаризацију драме, треба напоменути да су као драмски писци ипак имали скромна достигнућа. Док је теорија имала великог одјека свуда у свету и допринела конституисању модерне драме као књижевне врсте и новог позоришног облика, пракса је остала без дела вредних помена. Представници романтизма не успевају да изнедре драмско дело већег уметничког значаја, те се њихова доктрина углавном задржава на пуком теоретисању. Одличан пример за то је Игоов Кромвел: док је Предговор драми због свог доприноса развоју теорије драме, али и дефинисању поетике романтизма уопште, имао великог утицаја у Француској и у читавом свету, сама драма прошла је неславно и није доживела ниједну сценску адаптацију. Како читамо у коментарима уредника француског издања, због дужине од 6413 стихова, великог броја ликова и техничких потешкоћа у постављању на сцену, Кромвел није ниједном одигран у позоришту (IGO 2004: 121).

За неуспех романтичарских драматурга можемо пронаћи два објашњења. Једно даје Жак Бони (Jacques Bony) у књизи Читати романтизам (Lire le romantisme):

„Реализације драматурга романтичара нису на висини њихових великих амбиција: васкрснути историју, дубоко мешати жанрове, изражавати дуалност човековог бића - све ово исувише се често своди на употребу мелодрамских рецепата у корист заплета који, мада с ликовима другог ранга, ипак поставља проблеме блиске онима које је обрађивала грађанска драма“"(BONI 2001: 107). ${ }^{23}$

Према Бонију, покушавајући да класичну трагедију приближе

23 «Les réalisations des dramaturges romantiques ne sont pas à la hauteur de leurs grandes ambitions : ressusciter l'histoire, mêler intimement les genres, exprimer la dualité de lêtre humain, se réduisent trop souvent à l'utilisation des recettes du mélodrame au service d'une intrigue qui pose, malgré le rang des personnages, des problèmes proches de ceux que tratait le drame bourgeois. » 
свакондевљу и обичном животу обрађивањем друштвено-историјских тема и постављањем етичких питања, романтичари се тематски нису много удаљили од грађанске драме као претече и оснивача драме у ужем смислу. Уз то, инсистирајући на наглашеном приказивању страсти и патетичног, као и на помпезности израза и раскоши декора, романтичарска драма није успела да прекорачи ограничене уметничке домете мелодраме која је цветала у време Царства и Реастаурације.Мада Бони напомиње да би било претерано рећи да се романичарска драма само по предмету, који је углавном историјски, и стилу разликује од мелодраме, чини се да њен квалитет ипак остаје упитан (BONI 2001: 105, 106, 107).

Друго, делимично противно објашњење, нуди Џорџ Стајнер. Намера романтичара није била да одбаце трагедију зарад драме као новог позоришног облика (чему иде у прилог Стендалов избор термина национална трагедија у прози), већ да је ревитализују, осавремене и прилагоде сопственом тренутку. После 17. века, а нарочито након пада монархије после буржоаске револуције крајем 18. века, поред измењеног државног уређења, у француском друштву дошло је до велике духовне промене. Животне навике, моралне вредности, начела у васпитању и правила у понашању аристократа у време Луја XIV постала су далека и страна модерном грађанском друштву, а кључну промену донео је рационални емпиризам. Стајнер објашњава: док су се грчка и елизабетанска публика преко маште, мита и религије упуштале у свет надреалног и трансценденталног, те су божанска милост и казна као врховни регулаторни принцип, судбинска предодређеност, разни религијски обреди и вештичји ритуали били присутни у позоришту од Есхила, преко Шекспира, па све до Расина (мада су већ у његово доба западали у све већа искушења), такве концепције постале су потпуно неодрживе у модерном друштву 19. века које предводе велики философски и научни умови попут Декарта, Њутна и Волтера (STAJNER 1979: 137, 138). Зато су трагичко наслеђе античке културе и појмови попут части, фаталности, кривице и сл. постали неприменљиви у новом друштвено-историјском поретку, те је романтичарски покушај ревитализације трагедије био узалудан.

Следећи Стајнерову аргументацију, долазимо до закључка да то што романтичари нису били способни да ревитализују трагедију није њихова кривица, нити је проблем лошег укуса и несрећног одабира тема, већ се разлог њиховог неуспеха налази у сплету друштвених околности, политике и духа модерности који је донео рационализам, а који они нису били способни да сагледају у свој његовој свеобухватности. Иго није имао право када је у Предговору Кромвелу у оквиру теорије о три доба (théorie des trois âges) изнео став да трећем, модерном добу човечанства највише одговара драмска уметност као најзрелији израз човекове лич- 
ности. Романтичари су погрешно настојали да духовним тежњама свог времена дају драмски облик; оне су се, како примећује Стајнер, најбоље могле уобличити романом који „nije bio tek pokazivač novog, svjetovnog, racionalističkog, privatnog svijeta srednje klase“, већ је послужио „і kao književni oblik koji točno pristaje fragmentiranoj publici moderne urbane kulture“ (STAJNER 1979: 137). Да је роман право плодно тле за романтичаре потврђује управо пример Виктора Игоа који је, мада се опробао као драмски писац, далеко познатији и признатији као романсијер.

\section{6. Расин и(ли) Шекспир}

Мада је сагледавање практичних домета теорије драме француског романтизма указало на чињеницу да је романтизам у позоришту ипак инфериоран у односу на класицизам, након детаљног разматрања основних теоријских постулата романтичарске драматургије ипак можемо закључити да неуспели комади не умањују значај романтичарској теорији драме која остаје ослонац драми у ужем смислу какву познајемо данас, а коју су учврстиле надолазеће поетике с краја 19. и прве половине 20. века. Баш као што ни француска буржоаска револуција није одмах донела остварење политичких идеала јер је, после пада Прве републике, Француска више од седам деценија осциловала између републике, царства и монархије, она ипак представља кључни заокрет у историји Француске и читавог западног света. Како Стајнер наглашава, иако неостварен, романтичарски покушај конституисања драме важан је због тога што је дао низ бриљантних дела која стварају прелаз из раноромантичког раздобља у ново доба Ибзена и Чехова (STAJNER 1979: 138). Романтизам je, нагласимо то, утро пут драми као позоришном облику ослобођеном од свих античких и неоантичких поетичких норми, митолошких тема и стиха као јединог правог израза. У романтичарској теорији драма је еволуирала из псеудоантичке трагедије у нови, самостални позоришни облик који ће постати огледало савременог човека и његове духовности.

Стајнер напомиње и то да је намера романтичара била да кроз драму сједине грчку и шекспировску драму у нов тотални облик, способан да врати у живот древне моралне и песничке одговоре, али да та синтеза није била остварљива у добу научног рационализма када поменуте конвенције више нису одговарале стварностима мишљења и осећања (STAJNER 1979: 138). А управо тај покушај синтезе античког и модерног јесте кључ разумевања романтичарске драматургије. Мада је романтизам настао као реакција на класицизам, те је романтичарска драма требало да представља антипод класичној трагедији, трудили смо се да покажемо да је у ствари треба разумети као покушај њене трансформације, као и да се романтичари нису непријатељски и с ниподаштавањем односили 
према класицизму и великим ауторима те епохе. Напротив, ма како парадоксално изгледало, Иго и Стендал у својим драматуршким списима одају омаж Расину, ${ }^{24}$ а критикују неталентоване настављаче његове традиције и имитаторе кроз 18. век, док сама њихова тежња да ослободе трагедију од нормативне поетике класицизма не представља одрицање од овог драмског облика, већ управо супротно - њу треба разумети као својеврсно признавање трагедије као врховне књижевне врсте коју настоје да прилагоде духу свог времена.

Стога, полемику око Расина и Шекспира, тј. класичне трагедије и романтичарске драме, не треба свести на строги избор између две опозитности које се међусобно искључују. Напротив, саставни везник $u(e t)$ који стоји у наслову Стендаловог списа, управо упућује на уједињење два наочиглед различита поетичка става - дакле, не Расин или Шекспир, већ Расин ㄸ Шекспир. Такав спој указује на јединство уметничке визије која подразумева и Расинову савршену форму и узвишеност израза која одваја уметнички обликовано дело од баналног свакодневља, али и Шекспирово кршење правила јединстава времена и места, те увођење гротескног, страшног, ружног; и универзалност тема, али и слободу имагинације и неспутаност креације; и позивање на узоре у смислу настављања одређене уметничке традиције и неговања ванвременских вредности, али и обраду актуалних тема и догађаја из човекове блиске стварности; и конвенционалност дела, али и његову аутентичност, оригиналност. Речју, суштина је у сједињавању класичарског и романтичарског, а не у њиховом раздвајању како се често погрешно интерпретира Стендалова мисао. На овом месту ваља се подсетити Деридине идеје по којој се свако искуство, па и књижевно, састоји од два супротна пола који се међусобно допуњавају - од идиома и институције:

„Идиом указује на догађајни и јединствен карактер књижевног дела, а институција на његову конвенционалност. Идиом и институција се узајамно допуњавају: потпуно идиоматско дело би било несхватљиво, а потпуно институционализовано дело - лишено оригиналности“ (BUŽINJSKA 2009: 401).

И баш се на споју супротних полова, на деридијанској деконструкцији ради конструкције родила теорија драме француског романтизма која се није одрекла класичарске поетике, већ ју је наставила, допунила и делом трансформисала. Управо ће на тој щекспиризацији расиновског модела и романтизацији класичне трагедије почивати поетичка визија драме све до њене потпуне декон-

24 Из тог разлога иронични коментар Маријане Бири која романтичарску теорију драме своди на ниво покушаја и неуспелог пројекта, те закључује да су романтичари и после „пуно буке ни око чега“ наставили да читају Расина и да се инспиришу његовим делима чије су стихове знали напамет (BIRI 2003: 665) сматрамо излишним. 
струкције у театру апсурда у другој половини 20. века.

\section{Цитирана литература}

BIRI 2003: Bury, Mariane. « Racine et Shakespeare dans la bataille romantique : beaucoup de bruit pour rien ». In : Jean Racine 1699-1999, Actes du colloque du tricentenaire (25-30 mai 1999), p. 645-666. Sous la direction de Gilles Declecq et de Michèle Rosellini. Paris : PUF, 2003.

BONI 2001 : Bony, Jacques. Lire le romantisme. Collection «Lire » dirigée par Daniel Bergez. Paris : Nathan/HER, 2001.

BUŽINJSKA 2009: Bužinjska, Ana i Mihail Pavel Markovski. Književne teorije XX veka. S poljskog prevela Ivana Đokić. Beograd: Službeni glasnik, 2009.

DŽAKULA 1978:Džakula, Branko. „Francuska književnost prosvetiteljstva. Prvo razdoblje: od Belovog Pisma o kometi do Perzijskih pisama“, str. 13-43, i „Drugo razdoblje: od Perzijskih pisama do Enciklopedije“, str. 43-109. Džakula, Branko et al. Francuska književnost II (od 1683. do 1857). Sarajevo-Beograd: Svjetlost-Nolit, 1978.

KOLJEVIĆ 1992: Koljević, Nikola et al. Rečnik književnih termina. Beograd: Nolit, 1992.

LAGARD, MIŠAR 1969 : Lagarde, André et Michard, Laurent. Collection littéraire Lagarde \& Michard: XIX siècle. Paris-Montréal : Bordas, 1970.

LEJO 2005: Leuilliot, Bernard. Introduction in Stendhal. Racine et Shakespeare. Collection Rencontres dirigée par Antonia Fonyi. Paris : Éditions Kimé, 2005.

PAVLOVIĆ 1978: Pavlović, Mihailo. „Francuska književnost romantizma.Drugo razdoblje: od Meditacija do Gospođe Bovari“, str.239-295. U: Džakula, Branko et al. Francuska književnost II (od 1683. do 1857). Sarajevo-Beograd: Svjetlost-Nolit, 1978.

PETI 1968: Petit, Karl. Le Livre d’or du Romantisme. Limbourg : Marabout Université, 1968.

STAJNER 1979: Steiner, George. Smrt tragedije. Prijevod: Giga Gračan. Zagreb: Centar za kulturnu djelatnost Saveza socijalističke omladine Zagreba, 1979.

VUČELJ 2012: Vučelj, Nermin. „Didaktički teatar epohe francuskog prosvetiteljstva“. Filološki pregled, br. 34. Glavni urednik: dr Jelena Novaković. Beograd: Filološki fakultet Univerziteta u Beogradu, 2012. [orig.] Вучељ, Нермин. „Дидактички театар епохе француског просветитељства“. Филолошки преглед, бр. 34. Главни уредник: др Јелена Новаковић. Београд: Филолошки факултет Универзитета у Београду, 2012.

\section{Извори}

IGO 1967: Igo, Viktor. „Predgovor Kromvelu“. Odlomci prevedeni u: Gluščević, Zoran. Romantizam. Cetinje: Obod, 1967.

IGO 2004: Hugo, Victor. Préface de "Cromwell » : drame romantique. Édition présentée, annotée et commentée par Évelyne Amon. Paris : Larousse, Petits classiques, 2004. 
STENDAL 1953: Stendal. Rasin i Šekspir. Preveo Milan Predić. Beograd: Novo pokolenje, 1953. [orig.] Стендал. Расин и Шекспир. Превео Милан Предић. Београд: Ново поколење, 1953.

STENDAL 2005: Stendhal. Racine et Shakespeare. Introduction de Bernard Leuilliot. Collection Rencontres dirigée par Antonia Fonyi. Paris : Éditions Kimé, 2005.

Vanja V. Cvetković

\section{LA THÉORIE DU DRAME ROMANTIQUE : ENTRE RACINE ET SHAKESPEARE}

Cet article cherche à offrir une synthèse des idées principales de la théorie du drame romantique français qui représente à la fois une réaction contre la tragédie classique du XVII e siècle et une continuation de la théorie du drame bourgeois proclamé par Diderot au XVIII ${ }^{e}$ siècle. La nouvelle dramaturgie du XIX ${ }^{e}$ siècle a été constituée dans deux textes qui nous serviront de repère : Racine et Shakespeare de Stendhal et Préface de Cromwell de Victor Hugo. Pourtant, du point de vue contemporain, en prenant en considération les œuvres dramatiques du romantisme français qui navaient pas beaucoup de succès, il semble nécessaire de faire une réévaluation de la théorie. Cest dans ce sens-là que nous consulterons létude La Mort de la tragédie de George Steiner, afin de déterminer les aboutissements de la théorie du drame romantique. Au début, nous expliquerons la condition théâtrale, sociale et politique en France de la période choisie, puis nous présenterons le romantisme en tant que révolution littéraire dans le but de déterminer son caractère socio-politique et réfléchir finalement si la dramaturgie romantique est plus proche du système poétique de Racine ou de celui de Shakespeare.

Mots-clés : théorie du drame, dramaturgie, romantisme, Racine et Shakespeare, Préface de Cromwell, tragédie classique 